\title{
MILITARY LABOUR MOBILISATION IN COLONIAL LESOTHO DURING WORLD WAR II, 1940-1943
}

\section{Mary Nombulelo Ntabeni \\ Department of Language and Social Education, National University of Lesotho}

\begin{abstract}
In 1940, Great Britain's wartime exploitation of the human and material resources of its colonial empire was extended to colonial Lesotho (then known as Basutoland). The aim of this article, therefore, is to trace the four-year military labour mobilisation process in that colony, with special attention to the timing, number and procedures of the recruitment campaigns that were launched, the reasons for Basotho men's willingness or resistance to enlist, and the overall implications for Lesotho of large-scale absenteeism of able-bodied men as migrant and military labour.
\end{abstract}

\section{Introduction}

When Great Britain declared war against Germany on 3 September 1939, the whole British Empire was automatically at war. However, the actual entry into the war differed between 'lesser' colonies, like Lesotho, and dominions such as South Africa in that, unlike the former, the latter had an opportunity to debate and vote on the issue in their respective parliaments. Thus, depending on how they voted, the dominions effected their contribution to the war effort immediately thereafter while Great Britain instigated the involvement in active service of the Basotho and other southern African colonies only after the German invasion and the capitulation of France.

There is no doubt that the fall of Paris in June 1940 marked a critical turning point in the history of the Second World War, not only for Great Britain but also for the Allied forces and the world at large. Italy's entry into the war as Germany's ally compounded the situation further and, just nine months into the six-year war, Britain 


\section{7}

and its empire suddenly found themselves alone in defending the world against the German war machine and fascism. As could be expected, the drastic turn of events forced a dramatic change in British wartime policy for the colonial world. An all-out imperial war effort in the form of wider involvement of manpower and increased material resources from the colonies was launched in order to replenish and sustain the dire and constant needs of the 'mother country' to wage the total war.

Understandably, any general study of the overall wartime contribution of the African continent - be it in the context of a community, colony, region, or empire has to touch on the issue of labour mobilisation. Thus, there already exists a sizable collection of studies that discuss in detail all aspects of the recruitment and contribution of African labour during the Second World War. ${ }^{1}$ Still, there will always be a need to enrich the scholarship with wider geographical coverage and indepth research for all African countries that participated and/or contributed to the respective imperial war efforts because, as Jackson puts it, "assumptions still remain that can only be challenged or confirmed by case studies". ${ }^{2}$ This account of military mobilisation in Lesotho is one such case study.

Altogether, three main recruitment drives were launched in Lesotho between 1940 and 1942. The first recruits trained as part of the Native Military Corps (NMC) of the Non-European Army Services (NEAS) in the South African Union Defence Force (UDF), ${ }^{3}$ but were repatriated in 1941 to form the African [Auxiliary] Pioneer Corps (AAPC/APC) ${ }^{4}$ under which the last two labour recruitment campaigns of 1941 and 1942 were undertaken. Thus, by the end of the war in 1945, the numbers of Basotho men that had been recruited into four military contingents were as follows: 2000 in the NMC, 21463 in the APC, and another 4000 who re-/enlisted

\footnotetext{
${ }^{1}$ The best bibliography of studies on Africa and the World Wars in general, and southern Africa in particular, available at http://www.thuto.org/ubh/bw/ww/wwp1.htm (accessed on 22 February 2008).

2 A. Jackson, "Motivation and Mobilization for War: Recruitment for the British Army in the Bechuanaland Protectorate, 1941-42", African Affairs (1997), 96, p. 400.

3 Louis W.F. Grundlingh, "The Recruitment of South African Blacks for Participation in the Second World War" in David Killingray and Richard Rathbone (eds.), Africa and the Second World War (London: Macmillan, 1986), pp. 181-203.

4 This was a joint contingent of Basotho, Batswana, and Amaswazi servicemen. In 1944, "Auxiliary" was dropped from the original name and the acronym changed from AAPC to APC in recognition of the honourable record of the HCT Companies. See Public Record Office (hereafter PRO), DO 35/1183 Y1069/21 AAPC General: Change of title to APC.
} 


\section{8}

for the post-war service of garrison guard and clearing the war debris from 1946 to 1949. ${ }^{5}$

The purpose of this article, therefore, is to trace the successive stages of recruitment in Lesotho for the various contingents mentioned above from the time the colonial authorities planned to call up Basotho men into active service until the last group left for the war zone in 1943. The article further discusses the timing and number of campaigns, the terms of service, the methods and agencies of mobilisation and, lastly, the extent of the campaigns' successes when weighed against the prospective recruits' collaboration with and resistance to the draft.

\section{Basotho men in the Native Military Corps, 1940-41}

Following the fall of France in June 1940, Germany concentrated its offensive on Britain while Italy's entry into the war launched the Mediterranean and East African campaigns, to which the Allies responded under General Wavell from 1940 to $1941 .^{6}$ The greatest requirement for the Allies at that time was manpower as indicated by Wavell's incessant appeals "for more forces at once", 7 a message that the High Commissioner (HC) in Pretoria relayed to and impressed upon the respective Resident Commissioners (RCs) of the High Commission Territories (HCTs), that is, Basutoland, Bechuanaland, and Swaziland (now known as Botswana, Lesotho, and Swaziland - the BLS or BOLESWA countries). ${ }^{8}$

In accepting the new war demands of the colonial administration in 1940, King (Paramount Chief) Seeiso of Lesotho reaffirmed his nation's unswerving loyalty and long-standing willingness to serve in the imperial forces, and instructed his subordinates to prepare the nation for military labour mobilisation and training in

5 G Tylden, The Rise of the Basuto (Johannesburg: Juta and Co. Ltd., 1950), pp. 233-236; Jackson, "Motivation," pp. 399-400.

6 A Moorehead, African Trilogy: The North African Campaign, 1940-43 (London: Hamish Hamilton, 1965), particularly the foreword by Field-Marshall Viscount Montgomery, the Commander of the Eighth Army in which Basotho men served.

${ }^{7}$ B Gray, Basuto Soldiers in Hitler's War (Morija, Lesotho: Morija Printing Works, 1935), p. 5.

${ }^{8}$ A Jackson, Botswana 1939-1945: An African Country at War (Oxford: Clarendon Press, 1999) and "Supplying War: The High Commission Territories' MilitaryLogistical Contribution in the Second World War" The Journal of Military History 66 (July 2002), pp. 719-760; HS Simelane, "Labor Mobilization for the War Effort in Swaziland, 1940-1942”. The International Journal of African Historical Studies, 26 (1993), pp. 541-575. 
South Africa. ${ }^{9}$ At that time, the South African military authorities were "anxious that recruits should, as far as possible, be specially selected Natives who were likely, with training and experience, to make good non-commissioned officers". ${ }^{10}$ Therefore, this first campaign concentrated on the junior chiefs, the police force and other government employees who made up the first and, as it turned out, last group of 145 Basotho recruits that left for the Welgedacht NMC Training Depot in South Africa on 12 September $1940 .{ }^{11}$ They were given a resounding send-off with music, farewell speeches and words of praise, pride and encouragement from their fellow Basotho and cheering crowds as the soldiers marched to the train station. ${ }^{12}$

The Basutoland National Council (BNC) finally met in October 1940 to discuss, among other things, the first phase of military labour mobilisation that had already taken place. Some of the concerns raised by the BNC were still relevant, particularly for future campaigns. ${ }^{13}$ For example, the Councillors demanded proper military training and good treatment for their recruits, and sought clarification on the terms of service, pensions and obligation to serve in Europe. More importantly, the Councillors expressed serious concern about the incorporation of the Basotho recruits in the South African military because it must have revived all the ugly memories of the migrant labour system, South Africa's racial policies, and the issue of Lesotho's possible incorporation into the Union. However, overall, the senior indigenous rulers did not oppose the war. Even the anti-colonial Lekhotla la Bafo (LLB or The Commoners' League) was not anti-war as such, but vehemently against

${ }^{9}$ Moeletsi, 25 Phato (August) 1940. The King's letter, dated 14 Phupu (July) appeared on the front page. More or less the same sentiments were expressed during the First World War when the Basotho men served in the South African Native Labour Contingent.

${ }^{10}$ National Archives of South Africa, Pretoria, NMC NAS 3/4/1 B 8 Box 1, Note on a meeting held on 15 November 1940 to discuss recruiting of natives from the HCTs for service with Union forces.

${ }^{11}$ Mochochonono, 21 September 1940 . This is the only source that puts the number of the recruits at 120; all others quote 145. At the beginning, the Government Secretary would not reveal the number to the BNC, supposedly for security reasons but he later acknowledged, "we have sent only 145 men". Ex-serviceman Ntate Sanaha had quite a story to tell about their experiences and the honour they felt for being the first recruits. Also see L.A. Nalana, "The Second World War, 19391945/6: Its Significance for Lesotho Collaboration and Resistance" (1986).

${ }^{12}$ Interview, 'Mamoriee.

${ }^{13}$ PRO, DO 92/11, Proceedings of the $35^{\text {th }}$ Session of the BNC, 19-25 October 1940. 
military segregation and the elementary level of training that was given to Basotho and other African non-combatants. ${ }^{14}$

\section{The Formation of the African (Auxiliary) Pioneer Corps}

Throughout the phase of recruitment for the NMC, the traditional leaders of the HCTs pursued and eventually won the separation of their recruits from their neighbour's racist military institutions both at home and abroad. The move was first initiated by Kgosi Sechele of the Bakwena in Botswana and strongly supported by the kings (Paramount Chiefs) of Lesotho and Swaziland. ${ }^{15}$ However, theirs was a rather hollow victory because it rescued their soldiers from the clutches of the South African military but could not save them from the long reach of the military regulations that applied only to black recruits, including the APC. In other words, the formation of the APC and the immediate call for the men to join did not mean any changes in the regulations and terms of service, but it did remove them from the direct command of the South African officers.

\section{“Mokhosi o llile!"16: The 1941 APC Recruitment Campaign}

In 1941, the Allied Forces continued to face disaster and devastation in North Africa and the Middle East. The War Office consequently extended the Royal Pioneer concept throughout the empire in order to supply much needed manpower, particularly in the Middle East. ${ }^{17}$ In southern Africa, the new policy came into effect

\footnotetext{
${ }^{14}$ Robert Edgar, Prophets with Honour: A Documentary History of Lekhotla la Bafo (Johannesburg: Ravan Press, 1987), pp. 174-176: Document 39; "Basuto People Want Arms and Freedom. Lekhotla la Bafo Supports Soviets", Inkululeko, October 1941.

15 D. Kiyaga-Mulindwa, "The Bechuanaland Protectorate and the Second World War", Journal of Imperial and Commonwealth History, XII,3 (May 1984), p. 33-53; Brian Mokopakgosi III, "the Impact of the Second World War: The Case of Kweneng in the then Bechuanaland Protectorate, 1939-50" in Killingray and Rathbone, Africa, pp. 160-180; Simelane, "Labor Mobilization".

${ }^{16}$ This is a Sesotho translation referring to a call up (the alarm has sounded), be it to a pitso (traditional meeting) or to any other important event. This explains why it appears in the war song entitled "Song of the Warriors of Basutoland" in Gray, Basuto Soldiers, p. 2.

17 The various Pioneer Corps of the British Empire that were formed and deployed ahead of the APC are discussed in D Killingray, "Military and Labour Recruitment in the Gold Coast during the Second World War", Journal of African History, 23 (1982), pp. 83-95, and "Labour Mobilisation in British Colonial Africa for the War Effort, 1939-46" in David Killingray and Richard Rathbone (eds.), Africa and the
} 


\section{1}

in May 1941 when military officials met with the HC and the HCT governments to discuss the recruitment of additional pioneers. ${ }^{18}$

Meanwhile, the Basotho nation had experienced a leadership crisis following the untimely death of King Seeiso in December 1940, but it was resolved when his first wife, Mofumahali (Queen/Chieftainness) 'Mansebo, became the first female regent in the history of Lesotho's paramountcy. She was, therefore, in charge of the traditional leadership when the colonial authorities extended the pioneer corps service to Lesotho in mid-1941. At a pitso convened to welcome the HC in Lesotho, she reiterated her late husband's declaration of loyalty by assuring him that:

We are prepared to obey any call which we may be called upon to answer for the prosecution of the war and we are ready for any sacrifice which we may be asked to make to help His Majesty's Government to achieve victory. ${ }^{19}$

The speeches were a prelude to the imperial and the Regent's mokhosi oa ntoa (call-to-arms) in June 1941. As before, the "order" (ka taelo, as it says in the song) was disseminated throughout the chieftaincy and communicated to the people in the lipitso (traditional meetings). ${ }^{20}$ Nationwide recruitment started on 29 July $1941 .{ }^{21}$

\section{Recruitment procedure}

On this occasion, the recruitment organisation improved on the experiences of World War I and South Africa's NMC. In line with the implementation of other colonial labour policies, the chiefs became the major recruiting agents through the

Second World War (London: Macmillan, 1986), p. 70; PRO, DO 253/1, African Labour for the Middle East: History of Pioneers and Labour in the Middle East, 1940-1945.

${ }^{18}$ Simelane, "Labor Mobilization", p. 548. Between 23 and 32 members of the British Military Commission visited Swaziland, many of whom ended up as APC military officers. However, it was not possible to determine whether there was such a visit to Lesotho.

${ }^{19}$ Mochochonono, 21 June 1941.

${ }^{20}$ Mochochonono, 20 September 1941. There was a newspaper report (signed P.T.S.) on one pitso held at Tsikoane (Leribe District) on 16 August 1941. Unlike Lesotho's scheduling of the BNC late that year, the Swaziland National Council (SNA) had an opportunity to discuss and reject the recruitment, only to be railroaded by King Sobhuza; see Simelane, "Labour Mobilization", p. 548.

${ }^{21}$ Gray, Basuto Soldiers, p. 6. 


\section{2}

pitso system, and the recruitment procedure followed the same pattern for all of the voluntary campaigns. Generally, the chief was to call a pitso that covered his jurisdiction to provide information and encouragement to potential recruits based on government circulars that laid down the war aims, the terms and conditions of service and procedures for enlistment. ${ }^{22}$

To supplement the chiefs' activities and for handling problematic areas, the colonial authorities sent out recruiting personnel as needed in particular districts. These individuals often encountered a hostile reception since their presence was taken as an adverse comment on the competence of the local rulers. Sometimes, Basutoland Mounted Police (BMP) guides also helped with mobilisation. ${ }^{23}$

The medical requirements for APC recruits were as follows: ${ }^{24}$

\begin{tabular}{|c|c|}
\hline- & Age----------18-40 years \\
\hline- & Height-------at least 5 feet 3 inches $(1,6 \mathrm{~m})$ \\
\hline - & Weight------115 lbs minimum $(52,16 \mathrm{~kg})$ \\
\hline & Chest--------minimum of 32 inches fully expanded $(81 \mathrm{~cm})$ \\
\hline & Vision-------6/24 both eyes (or $6 / 12$ better eye, $6 / 36$ weakest eye) \\
\hline & Teeth---------a reasonable dental standard \\
\hline & Hearing------good in both ears \\
\hline
\end{tabular}

These health standards resembled those set for mine recruits performing the sort of heavy manual labour assigned to the APC personnel. ${ }^{25} \mathrm{~A}$ few of the Councillors

${ }^{22}$ As already indicated, two of the recruitment lipitso (pl.) - one in Matsieng and the other in Tsikoane - are described in the Mochochonono.

${ }^{23}$ Basuto at Arms: A Short Pictorial Record of the Basuto in War-time (London: Headley Bros., n.d.), 8-9; see also PRO, DO 119/1149 - Album of Photographs of Recruiting, Training and Entrainment of AAPC at Maseru, Basutoland, June to October, 1941. The two sources contain 15 and 71 captioned pictures/photos respectively.

${ }^{24}$ PRO, DO 35/1184/Y1069/2/3, AAPC Manpower: Middle East Requirements for Garrison Coys; Simelane, "Labor Mobilization", p. 549.

${ }^{25}$ Gray, Basuto Soldiers; Killingray, "Labour Mobilisation”, p. 73. 
volunteered to join if they passed the medical examination, but none was deemed eligible.

Wages in the APC, as in the South African NMC, were the lowest among the four racial sub-divisions in the armed services. Deferred pay was compulsory. The HCT soldiers were actually paid even less than South African blacks because they only got the basic pay and no allowances. ${ }^{26}$ A private with/out dependants earned $2 \mathrm{~s}$ $3 \mathrm{~d}\left(22 \frac{1}{2} \mathrm{c}\right)$ or $1 \mathrm{~s} 6 \mathrm{~d}(15 \mathrm{c})$ per day, which was then paid out in three parts. All the informants nominated their wives or mothers or some other relative as dependants, and so earned $2 \mathrm{~s} 3 \mathrm{~d}$ which made the pay divisible into:

\section{- $\quad 9 \mathrm{~d}\left(7^{1} / 2 \mathrm{c}\right)$ for the soldier's subsistence}

- $\quad 9 \mathrm{~d}(71 / 2 \mathrm{c})$ for the dependant, to be collected on a monthly basis

- $9 \mathrm{~d}(71 / 2 \mathrm{c})$ as deferred pay, to be collected at the end of the war

Other benefits were provided in the form of clothing/uniform, food, accommodation, health services and the like. Military wages were lower but, since deferred pay was compulsory, unlike on the mines, APC recruits accumulated large sums in the deferred pay account: $£ 193831$ (roughly R387 662) deposits and $£ 616$ 016 (roughly R1 232 032) withdrawals in 1946. The comparable figure for the mineworkers' voluntary remittances was $£ 311893$ (roughly R623 786), and most of the money ended up with the soldiers' families because many of them supplied labour to both the British army and the South African mines during the war. ${ }^{27}$

\section{Exemption}

As much as the colonial and military authorities were desperate for noncombatant labour, not every able-bodied Basotho man could be spared for military service. Thus, all those regarded as indispensable to the home front were exempted from enlisting on application by their employers ${ }^{28}$ or other authorities. Still, there is no clear indication of the specifics of the exemption policy from either official or oral evidence. It would seem that some individuals used exemption to avoid service.

${ }^{26}$ Grundlingh, "Participation", pp. 119-120.

${ }^{27}$ Colonial Annual Report (hereafter CAR), 1946.

${ }^{28}$ Archives of the Oblates of Mary Immaculate (OMI) Fathers, Maseru: Letter from Fr. Gravel to the RC's Office seeking exemption for all the indispensable men listed. It was not possible to verify whether this exemption was granted. 


\section{4}

Those who succeeded in avoiding recruitment often had influential connections, especially in 1942, when many potential recruits and their patrons tried anything and everything to avoid the army.

Schoolboys of all levels were exempted even though some of them met the army's minimum requirements. Thus, most of the schoolboys who joined the army were runaways - neither their parents/guardians nor the school authorities knew of their plans, even in cases where they deserted school in large numbers. ${ }^{29}$ The military authorities took them in without question or investigation. Even the Director of Education advised one informant to join the army instead of pursuing further studies. $^{30}$

Most Basotho believed that not all of their eligible family members should go and that the family should decide who would enlist, as they did under the migrant labour system. The intention was to spare the eldest sons since they were the heirs but, in the end, many families had more than one member in the military service because, according to one informant, the relatives could do little when the men decided to enlist. ${ }^{31}$

Basotho (and other African) women were never considered for active service at all, not even to take up such traditional non-combatant female duties such as nursing, entertaining and the like which were done by their Western counterparts. Their contribution was understood to be the usual staying at home and 'keeping the home fires burning'. Fortunately, the advent of the war and society approach in war studies has provided detailed scholarly works of the home front that constitute the contribution and impact of the two world wars on women. This approach has also led to many studies on women's roles in guerrilla warfare, such as that waged by the Mau-Mau in Kenya, the liberation struggles in southern Africa and many other wars of resistance worldwide. ${ }^{32}$

${ }^{29}$ Interviews, Mooki and Motselebane.

${ }^{30}$ Interview and comment, Mophethe and Monese respectively.

${ }^{31}$ Interviews, George, Molise and Palo.

${ }^{32}$ For the role of women in the liberation struggle of the African National Congress (ANC), see 'Women's Struggles' on http://www.anc.org.za/ancdocs/history/women [accessed on 01/09/08]. 


\section{5}

\section{Basotho men's response to the call-to-arms for the APC}

The formation of the APC in 1941 brought the NMC phase to an end and also launched a nationwide recruitment drive and its related concerns. The Resident Commissioner (RC) had assured the High Commissioner (HC) of large numbers of volunteers long before the call-to-arms was announced. ${ }^{33}$ The recruiters pursued their mandate by exploiting a nationalistic feeling by constantly referring to the home-based APC. The strategy paid off because the new corps attracted some Basotho working in South Africa who had resisted the NMC but chose to go back to Lesotho and join up there. One of the earliest APC recruits, who was working in South Africa in 1941, said that once he had decided to go to war, he wanted to enlist in sakeng la heso (literally, "my own or country's kraal"), meaning the APC. ${ }^{34}$

In many cases, the men made the decision to enlist without consulting their womenfolk or other family members. Men made their unilateral decisions in many different circumstances. For instance, there were men who went to the recruiting office, or who attended the pitso, not to learn what the recruiters had to come to say but rather to sign up because they had already made up their minds. In other cases, the men became caught up in the excitement of the moment in response to the fervent and eloquent calls at the pitso, and subsequently joined. ${ }^{35}$

Similarly, the younger generation often deserted their schools or work (herding, mining and the like), and ran away to join the army without consultation with their parents or guardians. Informants reported several attempts of women who tried to rescue such youngsters or who asked their men to do so, but in vain. ${ }^{36}$

Some families had to deal with men who were so determined to enlist that they crossed into South Africa after being rejected in Lesotho. One wife explained how shocked she was to learn that her husband, who left home apparently to go back to his job in South Africa, had instead joined the army. ${ }^{37}$

\footnotetext{
${ }^{33}$ Mochochonono, 28 June 1941.

${ }^{34}$ Interview, Nasoni (Sothoised Nelson).

35 Interview, Jonase.

${ }^{36}$ Interview, 'Mamoriee.

${ }^{37}$ Interviews, 'Mamaphoma and Filipi (Sothoised Philip).
} 


\section{6}

\section{Reasons for collaboration}

The first wave of enlistment in 1941 included those who had exercised an element of, if not complete, freedom of choice. Thus, the war removed many categories of men from the midst of the Basotho women, families and nation. Of the many reasons given for voluntary enlistment, the most common was economic. The war was seen as an opportunity for the unemployed in the sense that " $e$ ne ntse e le mosebetsi joaloka e meng" (it was a job like any other) for young men starting out in adult life to earn money for bohali (bridewealth) and marriage or to maintain a newly married wife and family. ${ }^{38}$ For some of the employed, the army was an alternative to working in South Africa. ${ }^{39}$

There were many other categories such as the "book people" (students and teachers); those driven by the spirit of adventure to see other parts of the world they had learned, taught, or dreamed about; ${ }^{40}$ runaways who were pulled into war by the unhappy circumstances of their lives; ${ }^{41}$ the otherwise unlikely military recruits for the war zone, including some from the evangelising and teaching missions; ${ }^{42}$ the saviours of family honour, such as one informant who enlisted when his older brother defied both the call-up and the wishes of their father; ${ }^{43}$ protégés of the khotla (the chief's/men's council) who, having been socialised by their elders' stories of traditional and modern warrior exploits in past wars, saw Hitler's war as a good chance to follow in their forefathers' footsteps; ${ }^{44}$ the principal chiefs and princes nominated or volunteering to lead their people into war; ${ }^{45}$ students who were brainwashed by expatriate educators about every Mosotho's sense of duty to combat Hitler's fascism and plans to enslave their mothers, ${ }^{46}$ and the victims of the glamour and novelty of recruiting propaganda, the military uniform and the women's special

${ }^{38}$ Interviews, 'MaOdilla, Emily, and 'Matankiso.

${ }^{39}$ Interviews, Matsepe. Like Filipi, he was turned down by the APC for being too short, and yet both were accepted by the NMC.

${ }^{40}$ Interviews, Selatiele, Mokhathi, Nasoni, Thabo, Simon, Gustav, Mphi, Kali and Thakalekoala.

${ }^{41}$ Interviews, Chaka, Lesang and Mophethe.

${ }^{42}$ Interview, Malibo. The three mainstream churches in Lesotho were headed by the Revs. Baccuet (PEMS), Pageau (RCC), and Ford (AC).

${ }^{43}$ Interview, Leshoele.

${ }^{44}$ Interview, George.

45 The nominated leaders included Chiefs Theko Makhaola (Qacha's Nek and PC's Representative), Khethisa Tau (Leribe), Mahlomola Masupha (Berea) and Mabina Lerotholi (Mokhotlong), all of whom were given the rank of Regimental SergeantMajor (RSM).

${ }^{46}$ Interviews, Maime, Mosoang, and Diaho. 


\section{7}

attention to the men in uniform. ${ }^{47}$ Thus, by the end of December 1941, eleven APC Basotho Companies (about 12000 recruits) were already serving in the Middle East.

\section{Reasons for not enlisting}

There were several reasons for avoiding military recruitment in Lesotho that were similar to those used in the rest of British Africa. In their testimonies, informants expressed great understanding for those men who chose to avoid enlistment and at the same time saving themselves and their families from the imperial war machine. At the same time, both male and female informants never failed to stress the difference between boithaopi (voluntary enlistment) in 1941 and sheshe or khohola-koqo (literally, "swept up in a torrential storm", as in being conscripted) in 1942. There was also a general perception that those men who did not join up during the voluntary recruitment campaign did not see themselves as resisters or could not be labelled such because they were exercising their right of choice.

Thus, during the fieldwork, it became difficult to locate or identify "genuine" resisters to the 1941 recruitment drive. This is where Grundlingh's suggestion becomes useful in that it classifies situations of refusal to join under the phrase "reasons for not enlisting", to imply reaction without action as opposed to resistance which implied outright defiant behaviour. ${ }^{48}$ In the study on which this article is based, only one informant expressed pride in his resistance and was willing to talk about the great lengths he went to in order to avoid military service. ${ }^{49}$

There were other factors behind the Basotho men's decision not to enlist. Some wanted to avoid danger that would lead to paying the ultimate price. ${ }^{50}$ After all, Lesotho suffered over 1000 casualties during the conflict. Other potential recruits were not convinced that they should lose their lives for a white man's war, the same sentiments that were expressed by the whites themselves in the South African War

${ }^{47}$ Interviews, Mooki and Motsarapane. Several female informants commented about how spiffy the men looked in their uniforms, especially at the end of the war when they all came back in their "battle dress" and in good physical shape.

${ }^{48}$ Grundlingh, "Participation", pp. 64-72.

${ }^{49}$ Interview, K'heisara (Sothoised Kaiser). My difficulty in locating more resisters and their reluctance to be interviewed when found out, came as no surprise. Many people did not understand why I wanted to include "makoala" (cowards) in a war study, so, they did not name them as informants except as examples of cowardice, which is an anathema in the Basotho society, especially for men.

${ }^{50}$ CAR, 1946, p. 66. 


\section{8}

or by non-whites during the First World War. For instance, one resister-informant justified his refusal to go to war by saying he "really had no quarrel with Hitler or the Germans" and about the nature of the fighting itself, "the enemy pounded you at a distance." ${ }^{51}$ Therefore, given the fact that the colonial and military authorities ultimately resorted to conscription, it is very likely that many Basotho resisters fell into these two categories.

If the Basotho and the other Africans were not ideologically motivated to risk injury or death in the cause of somebody else's war, the conditions of service were hardly conducive for them to change their minds. These conditions included poor remuneration, inadequate pension, indefinite contract for the duration of the war, hard labour far from home and lessons from World War I, with no guarantees of improved post-war conditions.

Lastly, the Basotho men were worried about the welfare of their families and loved ones during their (the men's) active service because they were the support financial, marital and emotional - of their folk. Therefore, many preferred the shorter and better defined labour contracts that made possible regular returns to family duties and responsibilities, such as the ploughing season. In other words, the South African mines were closer to home, the pay was better, and there were better options for handling family emergencies when necessary. This last point was particularly emphasised by Regimental Sergeant-Major (RSM) Theko Makhaola who encountered the same argument on one of his tours back home to come and boost recruitment. ${ }^{52}$

There was also the case of a letter to the Moeletsi ${ }^{53}$ by one Emmanuel B.N. Qhobosheane who made fun of the Basotho who enlisted, stating that they made him laugh because he did not understand how they thought their sticks and spears could stop the white man's warplanes [my translation]. Whether or not his views could have influenced some Basotho men's decision regarding recruitment for military service, is hard to tell.

On the whole, neither the Basotho women nor the men were able to do much to influence or minimise the impact of recruitment, particularly during the nightmare recruitment drive that was to follow in 1942 when conscription tactics replaced the voluntary system.

\footnotetext{
${ }^{51}$ Interview, K'heisara.

52 Proceedings, $37^{\text {th }}$ BNC Session, 1942.

${ }^{53}$ Moeletsi, 31 Mphalane (October) 1939.
} 


\section{Coercion and chicanery in the 1942 recruitment campaign}

In 1942, the war situation for the Allied forces in the Far East continued to deteriorate, culminating in the fall of Singapore. Consequently, Britain responded by intensifying the exploitation of its African empire's labour through conscription for the military and increased production demands on the civilians. Therefore, of the two APC major labour drives, the conscription episode generated the most information from both oral and written sources, mainly because of the intense efforts of both its proponents and opponents to enforce or thwart the process respectively. ${ }^{54}$ That is why, at the 1943 BNC Session, the RC was forced to admit that "[T]he debate makes abundantly clear the attitude of every Mosuto [sic] towards so-called 'voluntary recruiting' for the Army. There is no such thing - it is and always has been compulsion, naked and unashamed."

\section{Same procedures, different recruitment tactics}

The RC's admission makes it clear that when the Basotho men did not join up in the expected numbers, the colonial and military authorities in Lesotho embarked on a drastic change of recruiting strategies and tactics to raise the required servicemen. The Basotho chiefs were once again on the forefront of military recruitment, but with a lot of input and pressure from the colonial administration. For instance, once conscription had replaced voluntary enlistment, the recruitment depots were relocated from moreneng (the chiefs' residences) to the colonial administrative seats of all the nine districts. ${ }^{56}$ The lipitso were still called by the chiefs, but on behalf of the District Commissioners (DCs) and, therefore, held at the respective district camps. At the end of the recruitment session, when the medical examinations had been complete, only the rejects returned home while the recruits were no longer allowed to report at the training camp on specified dates, but were immediately taken from the district camps to Maseru, the capital town, for training.

In the process, some chiefs in the Matsekheng Ward became so overly overzealous that they tightened the screw on the prospective recruits by threatening to confiscate their land and livestock. ${ }^{57}$ Such threats were a powerful inducement in

\footnotetext{
${ }^{54}$ All the informants had one story or more to tell about the conscription period. For documented evidence, see PRO, DO 35/1183/Y1069/1/1: Minutes of the Secret Session of the Basutoland Council on recruiting for the AAPC, 26 October 1943.

${ }_{55}^{5 R O}$, DO/1183/Y1069/1/1: Minutes.

${ }^{56}$ Tylden, The Rise, p. 234.

${ }^{57}$ Interview, Motongoane.
} 
a society where the returns of its subsistence agriculture had been dwindling gradually since the late 1920s. In the same area there were cases where the people became pawns, caught between the pro-war Chief Nkuebe and adviser to the Regent and his half-brother and Principal Chief, Boshoane, who was very reluctant to support the recruitments. ${ }^{58}$ It was a classic example of local and national rivalries being played out over an imperial issue.

Besides the chieftaincy, the colonial, migrant labour and military authorities launched a concerted effort of their own to ensure that recruitment targets for military labour were met, whether by fair or foul means. They connived to suspend mine labour recruitment from July to December 1942, and used local Native Recruiting Corporation (NRC) offices and personnel for military purposes. ${ }^{59}$ Thereafter, both career and novice Basotho mineworkers were processed by (and sometimes falsely directed to) the military instead of the mine agencies. ${ }^{60}$ The deception shocked the family members who suddenly received the men's personal effects and notification to attend the next military dependants' payday. ${ }^{61}$

Shameless manipulation and deception of the Basotho men continued at the lipitso called by the chiefs and held at the DCs' offices in the respective district camps. One resister-informant testified that, as a resident of the Matsekheng Ward in the Berea District, he attended his Principal Chief's call-to-arms pitso which was held at the DC's office in Teyateyaneng (TY). There was a long wait which, as they later realised, was quite deliberate because when hunger and thirst set in, they were offered plenty of free joala (traditional beer made from sorghum) that was doctored with hard liquor. This plan worked because it quickly led to high levels of intoxication among the men, wild singing of mokorotlo (the traditional war song), simulated trampling of Hitler and his kind, and a large number of recruits thereafter. $^{62}$

58 Interview, Thabo.

${ }^{59}$ PRO, DO 35/925/Y432/7: Recruiting an Additional 15000 Natives for the AAPC and Possibility of Closing Mines to help Mobilise Natives.

${ }^{60}$ Interview, Matsepe.

${ }^{61}$ Interviews, 'Mamaphoma and Matsepe (wife and husband).

${ }^{62}$ Interview, K'heisara. He and his friend did not drink because they had brought their own mofao (traveller's provision, which usually consists of steamed bread and chicken), and they needed to stay sober to implement the plan they had devised in order to be rejected. Details about the same TY pitso were related by one of the informants interviewed by Nalana, "The Second World War", p. 18. He came from 
Informants also believed that during the 1942 recruitment campaign, medical standards were relaxed to increase the intake. One couple testified that the husband's poor teeth saved him in 1941 only to see him conscripted in 1942 despite the bad set of teeth. ${ }^{63}$ At the height of the conscription campaign when resistance was also most intense, the chiefs' scouts and government recruiters harassed the families and communities by going from door to door in search of resisters, and pulling them out of their hideouts such as under piles of blankets or behind lisiu (traditional grain silos) or libota (traditional stacks of firewood or cow-dung). Similar tactics were used in Swaziland ${ }^{64}$ and many other parts of British Africa. ${ }^{65}$ The colonial authorities also came down hard on the leadership and political activists of the LLB because they demanded proper military training for the recruits. The organisation was later banned and some of the leaders detained for the duration. ${ }^{66}$

\section{Resistance to the Khohola-koqo (conscription) of 1942}

Oral data and other sources show that the conscription resisters used all kinds of tricks at every stage of the 1942 coercive mobilisation process, from the call up to the day of departure for military service at Leboea (literally Up North - the battlefront). Simply 'failing' to show up at the chiefs' and/or DCs' lipitso continued to be the common way to avoid military service. ${ }^{67}$ One established action of resistance was to escape across the borders of South Africa and this intensified as soon as a pitso was called. ${ }^{68}$ Thus, the colonial and military authorities planted scouts at the train stations in Maseru and other border towns to waylay absconders who, in turn, learned to avoid the regular crossing points and travelled via circuitous

the same ward as my informant and there is no doubt that they were both at that pitso.

${ }^{63}$ Interviews, 'Matsotelo, 'Mamotselisi and Palo.

${ }^{64}$ Simelane, "Labor Mobilization", p. 558.

${ }^{65}$ Killingray, "Labour Exploitation for Military Campaigns in British Colonial Africa, 1870-1945", Journal of Contemporary History, 24 (1989), p. 483-501.

${ }^{66}$ Edgar, Prophets, 174-176; PRO, DO 35/1177/Y836/1 - LLB: Basutoland Correspondence with Mr. A. Jones regarding the internment of Josiel Lefela, Hlakane Mokhitli and Rapoho Nthonyana.

${ }^{67}$ Interview, K'heisara; Simelane, "Labor Mobilization", p. 558. He states that the Swazi men soon boycotted the chiefs' "bogus" meetings where they were rounded up into the army instead of discussing national affairs as was declared when convening the meetings.

68 All informants; Simelane, "Labor Mobilization". In many instances, the Malawians and Zimbabweans (then known as Nyasas and Southern Rhodesians respectively) merely crossed borders into the other neighbouring countries besides South Africa. 


\section{2}

routes into South Africa. The women abetted them by preparing the mofao (traveller's provision) for the long journeys towards freedom even though they knew that the men would have to become 'makholoa' (absconders for the duration of the war in some cases). ${ }^{69}$

In addition, the draft evaders used the medical examinations by deliberately rendering themselves 'unfit' for active service. Many informants testified that prospective recruits used cayenne pepper, snuff and other irritants to induce eye irritations; some men poured condensed milk into their ears to look like pus or as a secretion around the genitals. During the quick medical examination for military purposes, this could easily be mistaken for evidence of an infection, especially the much feared sexually transmitted diseases (STDs) that assured the men immediate rejection from active service. ${ }^{70}$ Self-inflicted injuries were also common, including the extraction of perfectly healthy teeth. Some men faked lunacy or mental disability by wearing their pants backwards, dressing as old women, or pretending to have a speech impairment, as in the case of 'Majepejepe'. ${ }^{71}$

As already indicated, other men like the resister-informant and his neighbour, went to the pitso with their own plan. They planned to fool the medical examiners by acting like deranged tuberculosis victims. They coughed incessantly, left mucus running from their nostrils into their mouths, and let the chicken blood they had brought from home drool from their mouths while waiting outside the examination room. Their appearance was so disgusting that nobody wanted to sit close to them and they both got exemption on sight the moment they walked in, without ever being touched by a doctor. ${ }^{72}$

During the 1942 coercive military recruitment, the recruiters went from door to door to apprehend the resisters in hiding. Thus, the harassment sent the resisterinformant and many other eligible Basotho men underground. Hiding from the recruiters took various forms, ${ }^{73}$ many of which required the women's cooperation. Basotho and Batswana resisters hid in lisiu/disigo (grain silos in the respective vernaculars) and caves as well as with distant relatives ${ }^{74}$ or fled into diphikwa (bush-

\footnotetext{
${ }^{69}$ Interviews, K'heisara and Likano.

${ }^{70}$ Interviews, Mophethe, Mohapeloa, Nasoni and 'Maneo, 'Masemapo, Frangeni.

${ }^{71}$ Comment by a passer-by during an interview.

${ }^{72}$ Interview, K'heisara.

${ }^{73}$ Mokopakgosi, "Impact”, p. 166; Simelane, "Labor Mobilization”, pp. 560-61; Killingray, "Labour Mobilisation”, pp. 75-6.

${ }^{74}$ Interview, Elizabeth.
} 
stacks), forests and other remote locations. The bush and hills also became havens for draft dodgers in Zimbabwe and Swaziland. If not in permanent hiding, the resisters countered the overnight raids by "sleep[ing] in the huts of the persons who are unlikely to be bothered on account of conscription (widows, old people)" ${ }^{75}$ There soon appeared a wide use of the common Basotho designation of women as bo-'Malifariki (literally mothers of pigs, meaning pig-owners) because it was associated with their frequent disappearances into the men's hiding places under the pretence of going to feed their pigs. ${ }^{76}$

Some of these hiding activities must have been humiliating to those who engaged in it, not so much because they feared that their wives and male friends would think of them as cowards but because they could actually be thought of as deranged, disgusting or terminally ill. However, the significance of this behaviour lies not so much in the acts themselves as in the reasons for them. The resisters were not always successful in avoiding active service, but their behaviour clearly demonstrated the intensity and lengths to which they were willing to go to avoid enlistment. Overall, resisters blamed their chiefs and the Regent for the implementation of the coercive measures - and rightly so - because, generally, the traditional leaders cooperated in the enforcement of the military recruitment policies. There were, however, cases of chiefs who supported the resistance and their stand and courage should be recognised. ${ }^{77}$

\section{Impact of wartime male absenteeism}

One of the most important aspects to consider regarding Britain's mobilisation of human resources in Lesotho during the Second World War is the overall impact that the large-scale absenteeism of able-bodied men had on the Basotho nation. The issue becomes all the more significant when understood in the context of a country that was a crucial "labour reserve" for South Africa's mining, farming and manufacturing industries long before the outbreak of the war. In other words, the phenomenon of male absenteeism was already a reality in the lives of the Basotho people. What the Second World War did, therefore, was to exacerbate some aspects of a familiar experience and/or introduce war-related versions of it.

\footnotetext{
75 Killingray, “Labour Mobilisation”, pp. 75-76; Simelane, “Labor Mobilization”, p. 561 .

${ }^{76}$ Interview, K'heisara and Maime; see Simelane, "Labor Mobilization”, pp. 560-1.

${ }^{77}$ Interview, Mokhathi.
} 


\section{4}

To start with, the war increased the rate of male absenteeism in Lesotho because military labour mobilisation was introduced alongside migrant labour recruitment. Even when the advent of conscription in 1942 dictated a temporary suspension of migrant labour recruitment in order to increase the number of military recruits, many resisters escaped the draft by going to South Africa. Thus, by the end of the war in 1945 and demobilisation a year later, a total of about 21463 men (out of a population of 559273) or 52 APC Basotho Companies had been recruited for military service up north, and 42472 were migrant labourers. ${ }^{78}$ Therefore, based on the high numbers of Basotho men who were absent from the country in the early 1940s and the network of kin relations through the extended family structure, one can safely state that there was not a single family in Lesotho that was not subjected to male absenteeism in the early 1940 s.

The absence of such a large numbers of men affected the socio-economic and political spheres of the Basotho society for the duration of the war. For instance, the principal chiefs who were nominated to lead the Basotho contingent into war as regiment sergeant majors (RSMs) left their chieftaincies in the hands of caretakers, a situation which like any other acting status at times rendered them vulnerable to indecision or pressure. At the same time, the few men and all the women and children who were left behind had to bear the added burden of their families' and colonial government's wartime demands such as being de facto heads of households, unbalancing the sexual division of labour by forcing most of the women to fulfil the absent men's responsibilities in agriculture and animal husbandry as well as their own chores, and that at a time when the government introduced the "food for war" policies which, in turn, increased child labour, and living with the loneliness and the fear for the servicemen's lives. ${ }^{79}$

${ }^{78}$ CAR, Basutoland 1947, pp. 15-17.

${ }^{79}$ For a detailed account of Lesotho's home front, see MN Ntabeni, War and Society in Colonial Lesotho, 1939-1945 (PhD thesis, Queen's University at Kingston, Canada, 1996); “The Impact of the Second World War on Basotho Women: Agricultural Subsistence and the War Effort", Journal of Southern African Studies, vol. 4, no.1 (June 2000), pp.1-18; "The Impact of the Second World War on Basotho Women and Family Relations" in A.H. Jeeves and O. Kalinga (eds.), Communities at the Margin: Studies in Rural Society and Migration in Southern Africa, 1890-1980 (Pretoria: Unisa Press, 2002), pp. 36-51. 


\section{Conclusion}

This article has covered four years of colonial Lesotho's war effort during the Second World War, with special attention to military labour recruitment. It has shown how the vicissitudes of the war dictated the timing, number and procedures of the recruitment campaigns that Britain launched in Botswana, Lesotho, and Swaziland. The first voluntary recruitment of Basotho servicemen - and not women - into a South African black contingent in 1940 was followed by the establishment of a new joint contingent, the African (Auxiliary) Pioneer Corps, and a countrywide military labour mobilisation in 1941. Similarly, the dire turn of events for the Allied forces in the Far East in 1942 ushered in an even more pressing demand for military labour, hence the change of recruitment policy from voluntary joining up to conscription.

For their part, the Basotho men who volunteered for active service in 1940-1941 were propelled by a variety of reasons, ranging from adventure to employment opportunities. Those who chose not to join were mostly not convinced about serving, and even dying, in a distant war that had nothing to do with them. The launch of the draft provided the means to pursue the targeted quota but it undermined the prospective recruits' right of choice, and also heightened the defiant spirit of the Basotho resisters and some of their leaders. Therefore, the resisters embarked on several strategies of dodging conscription. Still, judging by the large number of Basotho servicemen in the Second World War, military recruitment in Lesotho between 1940 and 1943 could be viewed as a success for the colonial and military authorities (especially when compared with the experiences of World War I), but it inflicted negative socio-economic and political effects on the Basotho nation, as indicated.

As far as recommendations for further research on Africa and the World Wars are concerned, Lesotho's realities of military labour mobilisation demonstrate why this phenomenon constitutes a very crucial aspect of Africa's contribution to the respective imperial war efforts during the Second World War. In other words, detailed analyses of this nature are necessary to inject the African voice and perspective into the World War narratives which, for a long time, sidelined the continent's involvement. The available literature on Africa and the two World Wars provides enough valuable information for further comparative exercises at different levels such as among the African territories of the same or different empire(s); within a country like Lesotho where there was competition for migrant and military labour during the war years; or between distinct regions and/or ethnic groups in certain colonial states like Botswana. 


\section{6}

\section{Source list}

Basuto at Arms: A Short Pictorial Record of the Basuto in War-time. London: Headley Bros., n.d.

Basutoland Census 1936. Maseru: Government Printing, 1936.

Colonial Annual Report 1946. Maseru: Government Printing, 1946.

Edgar, R. Prophets with Honour: A Documentary History of Lekhotla la Bafo. Johannesburg: Ravan Press, 1987.

Gray, B. Basuto Soldiers in Hitler's War. Morija, Lesotho: Morija Printing Works, 1935.

Grundlingh, LWF. "The Recruitment of South African Blacks for Participation in the Second World War". In Killingray, D and Rathbone, R (eds.). Africa and the Second World War. London: Macmillan, 1986.

Jackson, A. "Motivation and Mobilization for War: Recruitment for the British Army in the Bechuanaland Protectorate, 1941-42”, African Affairs, 1997.

Killingray, D. "Military and Labour Recruitment in the Gold Coast during the Second World War". Journal of African History, 23, 1982.

and Rathbone, R (eds.). Africa and the Second World War. London: Macmillan, 1986.

"Labour Mobilisation in British Colonial Africa for the War Effort, 1939-46". In Killingray, D and Rathbone, R (eds.). Africa and the Second World War. London: Macmillan, 1986.

"Labour Exploitation for Military Campaigns in British Colonial Africa, 1870-1945”. Journal of Contemporary History, 24, 1989.

Kiyaga-Mulindwa, D. "The Bechuanaland Protectorate and the Second World War". Journal of Imperial and Commonwealth History, XII, 3, May 1984. 


\section{7}

Mokopakgosi III, B. "The Impact of the Second World War: The Case of Kweneng in the then Bechuanaland Protectorate, 1939-50". In Killingray, D and Rathbone, R (eds.), Africa and the Second World War. London: Macmillan, 1986.

Moorehead, A. African Trilogy: The North African Campaign, 1940-43. London: Hamish Hamilton, 1965.

Nalana, L.A. "The Second World War, 1939-1945/6: Its Significance for Lesotho Collaboration and Resistance” B.A Ed., History dissertation, 1986.

NMC, NAS 3/4/1 B 8 Box 1, Note on a meeting held on 15 November 1940 to discuss recruiting of natives from the HCTs for service with Union forces.

PRO, DO 253/1, African labour for the Middle East: History of Pioneers and Labour in the Middle East, 1940-1945.

PRO, DO 119/1149 - Album of Photographs of Recruiting, Training, and Entrainment of AAPC at Maseru, Basutoland, June to October 1941.

PRO, DO 35/925/Y432/7: Recruiting an Additional 15000 Natives for the AAPC and Possibility of Closing Mines to help Mobilise Natives.

PRO, DO 35/1184/Y1069/2/3, AAPC Manpower: Middle East Requirements for Garrison Coys.

PRO, DO 35/1177/Y836/1 - LLB: Basutoland - Correspondence with Mr. A. Jones regarding the internment of Josiel Lefela, Hlakane Mokhitli and Rapoho Nthonyana.

PRO, DO/1183/Y1069/1/1: Minutes of the Secret Session of the Basutoland Council on recruiting for the AAPC, 26 October 1943.

Simelane, SH. "Labor Mobilization for the War Effort in Swaziland, 1940-1942". The International Journal of African Historical Studies, 26, 1993.

Tylden, G. The Rise of the Basuto. Johannesburg: Juta and Co., Ltd., 1950. 


\section{Newspapers}

Mochochonono (The Comet)

Moeletsi oa Basotho (The Adviser of the Basotho)

\section{Interviews}

1. Nasoni Hlasa, Bela-Bela (moreneng), 15 October 1990

2. 'Masemapo Peete, Bela-Bela (moreneng), 17 October 1990

3. Palo Khachane, Morapamiseng, Bela-Bela, 17 October 1990

4. K'heisara Nyamane, Tokolohong Bela-Bela, 19 October 1990

5. Maime Mojakisane, Ha Mahlabachana, Bela-Bela, 26 October 1990

6. 'MaOdilla Lieta, Ha Mahlabachana, Bela-Bela, 28 October 1990

7. Emily 'Neko, Tuke, Bela-Bela, 1 November 1990

8. Lesang Ntisa, Ha Ntisa, Bela-Bela, 5 November 1990

9. Motongoane Sello, Mokomahatsi, Bela-Bela, 13 November 1990

10. 'Matankiso Hlaoli, Mokomahatsi, Bela-Bela, 14 November 1990

11. Mooki Maphasa, Mokomhatsi, Bela-Bela, 14 November 1991

12. Mphi Sekoati, Bakaneng, Bela-Bela, 17 November 1990

13. Motarapane Tlali, Mokomahatsi, Bela-Bela, 14 Novemebr 1990

14. Thabo Nkuebe Peete, Corn Exchange, Bela-Bela, 21 November 1990

15. Simon Mokoaleli, Kolojane, Bela-Bela, 27 November 1990 
16. Hunter Setsomi Sebatane, Hlotse, Leribe, 26 February 1991

17. Leshoele Leshoele, Ha Leshoele, Leribe, 26 February 1991

18. Kali Sekete, Ha Leshoele, Leribe, 26 February 1991

19. Gustav Ts’osane, Ha Leshoele, Leribe, 26 February 1991

20. George Bereng, Naleli, Maseru, 10 \& 11 April 1991

21. Salatiele Thakholi, Levi’s Nek, Leribe, 7 May 1991

22. John Monaheng Diaho, Maoana-masooana, Leribe, 8 May 1991

23. Arone Malibo, Mazenod, Maseru, 16 May 1991

24. Likano Setho, Ha Mafefooane, Roma, 8 August 1991

25. 'Mamaphoma Sejanamane, Borokhoaneng, Maseru, 29 August 1991

26. Matsepe Sejanamane, Borokhoaneng, Maseru, 29 August 1991

27. John K. Mohapeloa, Fokothi, Maseru, 4 September 1991

28. E.T. Mophethe, Education Offices, Maseru, 6 September 1991

29. Sanaha Ntlaloe, Qoaling, Maseru, 10 September 1991

30. 'Mamoriee Khaebana, Seputana, Maseru, 14 September 1991 